\title{
Epigenetic Alterations in Cellular Immunity: New Insights into Autoimmune Diseases
}

\author{
Zijun Wang ${ }^{a}$ Zhihui Wang ${ }^{b}$ Qianjin Lu \\ aDepartment of Dermatology, The Second Xiangya Hospital, Central South University, Changsha, \\ China; 'Department of Environmental Health, Harvard T.H. Chan School of Public Health, Boston, \\ Massachusetts, USA
}

\section{Key Words}

Epigenetic modifications - Cellular immunity - Systemic lupus erythematosus (SLE) • Rheumatoid arthritis (RA) • Systemic sclerosis (SSc) • Type 1 Diabetes (T1D)

\begin{abstract}
Epigenetic modification is an additional regulator in immune responses as the genome-wide profiling somehow fails to explain the sophisticated mechanisms in autoimmune diseases. The effect of epigenetic modifications on adaptive immunity derives from their regulations to induce a permissive or negative gene expression. Epigenetic events, such as DNA methylation, histone modifications and microRNAs (miRNAs) are often found in T cell activation, differentiation and commitment which are the major parts in cellular immunity. Recognizing the complexity of interactions between epigenetic mechanisms and immune disturbance in autoimmune diseases is essential for the exploration of efficient therapeutic targets. In this review, we summarize a list of studies that indicate the significance of dysregulated epigenetic modifications in autoimmune diseases while focusing on T cell immunity.
\end{abstract}

\section{Introduction}

Epigenetic modification is known as a gene-environmental term that characterized by the process of regulating gene expression as well as cellular function without changing DNA sequence [1]. Epigenetic dysregulation activate a range of human diseases and also has been linked to diverse pathological processes, especially in autoimmunity [2]. Due to the epigenetic bridge which links the gene and environment factors to contribute to immunity, the studies have shown the emergence of more epigenetic regulations in autoimmune diseases. Immune events occur in the presence of epigenetic modifications, owing to their molecular mechanisms in immune system by influencing overreactive immune cell functions in autoimmunity.

Qianjin Lu

KARGER
Department of Dermatology, The Second Xiangya Hospital, Central South University, \#139 Renmin Middle Road, Changsha 410011 (China)

Tel. +86-731-85295860, Fax+86-731-85533525, E-Mail qianlu5860@gmail.com 


\section{DNA methylation}

DNA methylation as a stable component in the epigenome has been a topic of intense interest. DNA methylation is implicated to cause gene repression, reversible promoter silencing and chromosomal instability $[3,4]$. As a mechanism for altering transcription activity through certain modifications, DNA methylation is of great importance among epigenetic mechanisms, by which gene expression can be manipulated. The methylation level in the exon 1, which is in the downstream of the transcriptional start sites (TSS), is firmly connected to gene silence [5]. In addition, the methylation in TSS is activated by some dsRNAs through RNA-directed DNA methylation (RdDM) pathway, eventually, leading transcriptional gene silencing(TGS) [6]. In mammalian genomes, the methylated cytosine is clustered in GC-rich regions, named CpG islands [7]. DNA methylation is characterized by cytosine methylation mediated by de novo DNA methyltransferase enzymes (DNMT) [8], including DNMT1, DNMT3a, DNMT3b, and DNMT3L. DNMT1 is essential for remethylation of hemimethylated CpGs in mammalian development, while DNMT3a and DNMT3b are responsible for de novo methylation and carry out new methylations $[9,10]$. DNA demethylation, in conjunction with a group of permissive translation activities, promotes the combination of several transcription factors binding to distinct gene loci.

\section{Histone modification}

Histone modifications adjust chromatin structure and target gene expression by recruiting remodeling enzymes and using energy from ATP hydrolysis to reposition the nucleosomes [11]. The most common histone modifications include acetylation, methylation, ubiquitination, phosphorylation, sumoylation, citrullination, ADP ribosylation, and proline isomerization [12]. Among them, acetylation is typically related to either active or repressive gene expression activities by two enzyme families with relative regulations, histone acetyltransferases (HATs) and histone deacetylases (HDACs), therefore, is suggested to be reversible and dynamic. On the contrary, methylation is found to be more stable with long-term maintenance of the expression pattern in the genomic regions [13]. The process of histone methylation is alternative, depending on the two opposite enzymes that catalyze different biochemical reactions, histone methylases and demethylases. For example, H3K4 trimethylation is suggested to upregulate gene expression; while H3K9 methylation and H3K27 trimethylation are known to downregulate gene expression. Convincing evidence shows that histone posttranslational alterations are significant regulators in the development of different cell lineages.

\section{MicroRNA transcripts}

MiRNAs are small noncoding single-stranded RNAs, consisting of a class of 21 to 23 nucleotide. The small noncoding RNAs as post-transcriptional and post-translational regulators are involved in gene expression by binding to target mRNAs. More than half of the protein-coding genes of mammals are found be encoded through thousands of miRNAs that corporately affect gene expression. By targeting the complementary sequences within 3' UTR of a transcript, miRNAs inhibit transcription activity of target gene, and/or reduce mRNA stability, thus alternatively regulating protein expression [14]. MiRNAs serve as a guardian at every checkpoint genetically, modulate effector cell function through the regulation of specific signaling pathway, or target genes. Dysregulation of miRNAs will lead to varieties of dysfunctions or disorders, such as malignancy to immune diseases, implicating that miRNAs are involved in the maintenance of homeostasis, more specifically, participating in hematopoietic development, and cell activation and differentiation [15]. Additionally, miRNAs have also been identified as fine-tuning regulators to manipulate diverse biological processes at post-transcriptional level [16]. 


\section{Cellular Physiology Cell Physiol Biochem 2017;41:645-660

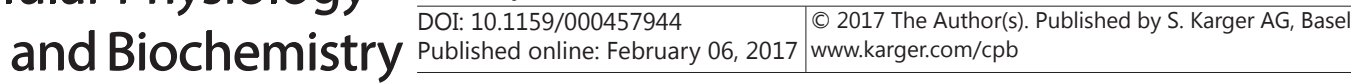 \\ Wang/Wang/Lu: Epigenetics in Immune System and Autoimmune Diseases}

\section{Thelper cell lineages}

In the immune system, the differentiation and function of T cell is a good model to study epigenetic regulation [17]. Increasing evidence suggests that epigenetic reprogramming participates in T cell activation, differentiation, and development, thus defines cell identity and function to environmental challenges [18]. Additionally, epigenome analyzing studies performed a range of high-resolution transcriptomic profiling of different kinds of immune cell including CD4+ T cells, and thus providing us with more knowledge of the uncovered story of T cell epigenetics [19].

Upon antigen stimulated, naïve $\mathrm{T}$ cell start their long term to travel to different $\mathrm{T}$ cell lineages. T helper 1(Th1) cell is important for controlling intracellular bacterial infection while T helper 2(Th2) cell initiates antibody response against extracellular pathogen. Tbet and Gata3 are major transcription factors for the induction of IFN- $\gamma$ and IL-4 gene expression respectively. Thelper 17 (Th17) cell is characterized by the expression of the key transcription factor retinoic orphan receptor $\gamma \mathrm{t}$ (ROR $\gamma \mathrm{t}$ ) and the production of IL-17A, IL-17F, IL-21 and IL-23 cytokines [20]. Th17 cell is considered to be protective against infections at mucosal surfaces as a distinct CD4+ effector lineage [21,22]. It was mentioned by Sakaguchi et al. in 1995that Regulatory T (Treg) cell cell could express Forkhead box P3 (Foxp3) and produce IL-10 and TGF- $\beta$ [23]. Treg cell is associated with peripheral tolerance and homeostasis in the immune system. Foxp3 is a transcriptional factor required to modulate the certain signaling mechanisms, and is considered to organize a perplexed transcriptional network which can stabilize the features and functions of Treg cell lineages [24]. T helper 9 (Th9) cell and T follicular helper (Tfh) cell are two subsets and were identified recently. Th9 cell is characterized by secreting IL-9 cytokine. It is not until recently have the studies found that Th9 is regulated by ETS family transcription factor PU.1, as well as IRF4 and GATA-3 [25-28]. Follicular helper T (Tfh) cell is featured as they localized in germinal centers to help B cells produce antibodies [29]. These Tfh cells express IL-21 cytokine (which is believed to be secreted only by Th17 cells) in addition to Bcl-6 (which is important for the development of B cells) [30, 31].

DNA methylation displayed a range of dynamic methylation/demthylation in $T$ cell lineages

Th1 and Th2 cell. Studies have shown that DNA methylation guides the Th1 and Th2 differentiation by regulating their Th1 cytokine (IFN- $\gamma$ ) and Th2 cytokine (IL-4, IL5 and IL13) gene expression, respectively [32]. In Th1 cells, IFN- $\gamma$ gene locus achieves permissive modifications such as DNA demethylation and histone $\mathrm{H} 3$ acetylation or trimethyl-histone H3 lysine 4 (H3K4me3), while Th2 cytokine loci obtain repressive histone modifications and DNA methylation. However, those epigenetic patterns are negatively displayed in Th2 cells. Th2 cytokine gene loci receive allowable histone marks but the IFN- $\gamma$ gene locus receives DNA methylation and repressive histone marks including trimethylation of histone H3 lysine 27 (H3K27me3) (Fig. 1) [33]. HS V is found to be DNA methylated in naïve T cells and de novo methylated during Th1 differentiation [34]. T-cell immunoglobulin and mucin domaincontaining protein 3 (TIM-3) has been found occasionally Th1 cell, which implies that some potential mechanisms may be linked with the TIM-3 and Th1 cell. DNA methylation analysis determines that a CpG island within the TIM-3 promoter is controlled by the regulation of DNA methylation. In vitro induced differentiation of Th0, 1 and 2 cell all displayed a DNA demethylation in that specific region of TIM-3 promoter, thus suggesting an increased expression of certain genes that encoded by the region of TIM-3 promoter [35].

Th17 and Treg cell. As discussed previously, similar histone remodeling and DNA demethylation occurs at IL17A and IL17F during the development of mouse Th17 cells, as the epigenetic regulation of Ifng locus and Th2 cytokine gene loci in the differentiation of Th1 and Th2 cells [36-38]. In vivo-isolated human Th17 cells are featured by DNA demethylation in IL17A and RORC loci, which is associated with specific expression in these cells [37, 39].

Many researches mentioned the critical roles of DNA methylation, in sustaining the steadily expressing of Foxp3 gene in association with Treg cell function. For example, Foxp3 


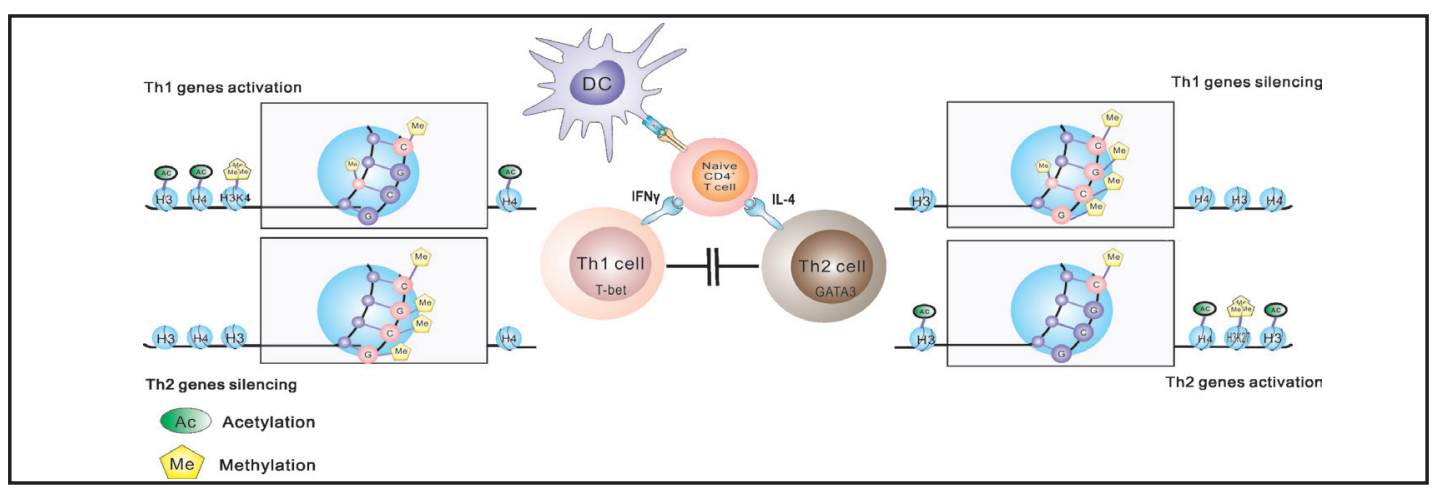

Fig. 1. Epigenetic modifications in Th1 and Th2 cell differentiation have been extensively analyzed at the Th1 (IFN- $\gamma$ ) and Th2 gene cytokine loci. In Th1 cells, Th1 cytokine gene (Ifng) gains hypomethylation and permissive histone modifications (H3 and H4 acetylation, H3K4me3) whereas Th2 cytokine genes gain DNA methylation and repressive histone modifications. Conversely, in Th2 cells, the Th2 cytokine locus gains active histone modifications and DNA hypomethylation while the IFNg locus gains repressive histone modifications and DNA methylation.

gene demethylation within Treg cells has been found in both human and animals (Fig. 2). However, those in vitro TGF- $\beta$-induced Treg cells (without epigenetic control) are identified to lose the stable expression of Foxp3 as well as the immunosuppressive function [40]. In a recent study, it has been noted that TET enzyme family do have a positive correlation with the long term expression of FOXP3 in TGF- $\beta$-induced Treg cells. Targeting TET enzymes by some certain molecular such as Vitamin $C$ that promote the oxidation process of $5 \mathrm{mC}$ to $5 \mathrm{hmC}$ which is tighly associated with DNA demethylation that induced FOXP3 gene overexpression [41]. Treg-specific demethylated region (TSDR) has known to be a characterized fragment within the Foxp3 gene. Emerging evidences proved that TSDR can be only detected in stable Treg cell phenotypes. Study has also found that a global demethylation profile is gathered in this region in natural Tregs but effector T cells [42]. Thus, these data performed a hallmark of TSDR makes it an effective biomarker in detecting Treg cell [43]. Therefore, the hypomethylation pattern in Treg cells plays a pivotal role in maintaining the lineage commitment, stabilization, and suppressive function of Treg cells. Recent studies have deciphered a series of hypomethylated genes (Foxp3, Ctla4, Ikzf4, and Ikzf2, which are prerequisites for the Treg phenotype) are also under the regulation of permissive histone modifications in Foxp3 promoter region [44-47]. A recent study conducted an interesting experiment which induced the production of human CD4+CD2 $5^{\text {hiFOXP3 }}+\mathrm{T}$ cell from normal CD4+CD25- T cells in the presence of DNA methyltransferase inhibitor 5-azacytidine (5-Aza) as well as a less suitable TCR stimulation. The successful induction of CD4+CD25+FOXP3+Treg cell under DNA methylation regulation implies that the differentiation process from CD4+ T cells to iTreg cell is controlled by DNA hypomethylation which may increase the expression of several regulatory genes, such as FOXP3 [48].

\section{Histone acetylation and H3K4 methylation are critical regulators in determining differentiation directions}

Th1 and Th2 cell. Th1 and Th2 cell differentiation are controlled by histone modifications in the Il4 locus with the involvement of cis-regulatory elements [49]. NFAT is a transcription factors of activated T-cells, which obtains an alternative and lineage-specifying function to selectively promote Th1 or Th2 cell differentiation due to different epigenetic regulations $[49,50]$. Histone hyperacetylation is suggested to be related with an open chromatin state, which is found in the promoter region of Ifng and IL4 gene in memory Th1 and Th2 cells, separately (Fig. 1) [51,52]. A large amount of studies have reported the important role of the combination of Histone $\mathrm{H} 3$ acetylation, Lys-4 tri-methylation (H3K4me3), and Trithorax G (TrxG) (a well-characterized epigenetic modulator in Th2 cell differentiation) [53, 54]. 


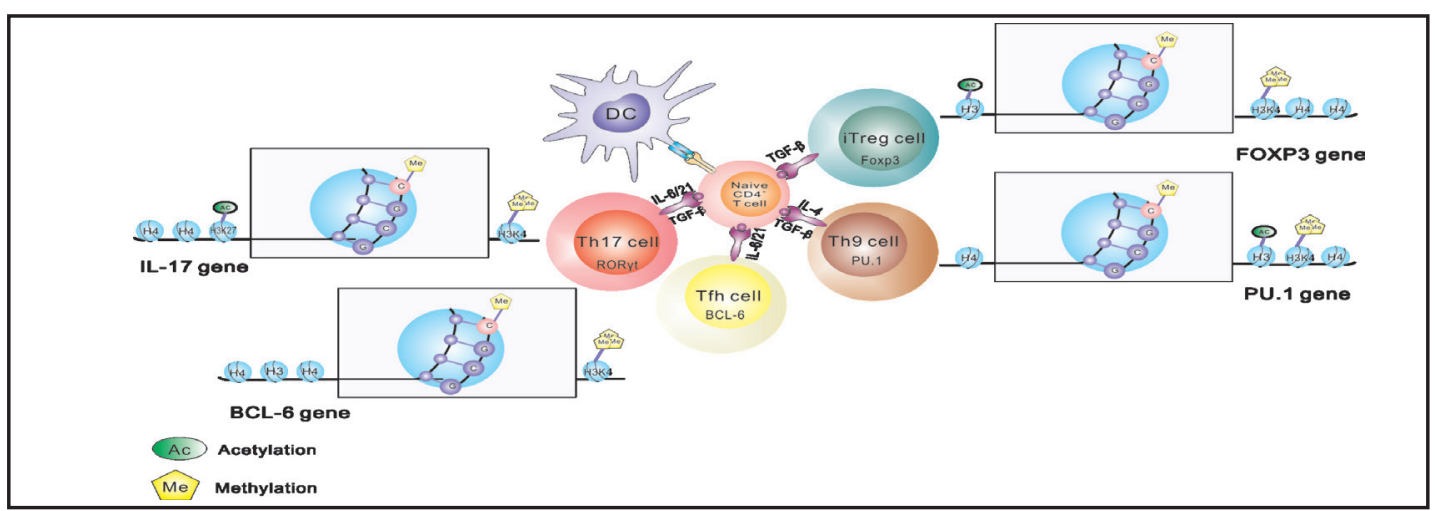

Fig. 2. Dynamic epigenetic changes are involved in the differentiation of Th17, iTregs, Th9, and Tfh cells, such epigenetic marks are permissive and especially regulated in their active genes. H3/H4 acetylation and H3K4me3 are specifically increased in the IL-17, FOXP3, PU.1 and BCL-6 gene promoters, which permit the differentiation from Naïve T cell into different effector T cells.

The production of TrxG complex happens when STAT6 is activated at the promoter region of GATA3, which is an important transcription factor in the Th2 cell development and differentiation [53]. Growth factor independence 1 (Gfi1) is a transcriptional inhibitor that enhances Th2 cell but suppresses Th17 and Treg cell differentiation. Studies recently target Gfi1 to explore its role in Th1 cell and a negative correlation has been found between Th1related transcription factors Gfi1. Gfi1 combines with those transcription factors of Th1 cell and a decreased expression of histone H3K4 methylation that is tightly associated with gene repression [55].

Th17 and Treg cell. The synergistic role of histone modifications in promoting chromatin accessibility for transcription factors is deciphered. H3K4me3 is specifically correlated with IL-17 and IL-17F gene promoters in Th17 cell subset. Upon stimulated, histone acetylation of IL17 gene is initiated by the combination of TGF- $\beta$ and IL-6 [36]. The role of H3K27 demethylase Jmjd3 is important in regulating Th17 cell differentiation since the combination of Jmjd3 with H3K27me3 within Rorc promoter promotes the process of H3K27 demethylation. An increased expression of Jmjd3 is induced by activating naïve CD4+ T cell to differentiation into T helper cells. Reversely, silencing Jmjd3 gene in CD4+ T cell caused a decreased number of Th17 cells. In vitro experiment of EAE mouse model in Jmjd3 knokout mice showed an alleviated symptoms and clinical scores. Therefore, Th17 cell differentiation is regulated by Jmjd3 induced H3K27 demethylation and deficiency of which may be carried out to inhibit the immune responses medicated by Th17 cells [56].

CBP and p300 bromodomains are two histone acetyltransferases which have been proved to play significant role in stabilizing Treg cell lineage commitment and differentiation [57]. The bromodomains interacts with histone acetylation thus increasing FOXP3 gene expression and sustain the Treg cell function and stability [58]. Histone/protein deacetylases (HDACs) are important enzymes in generating histone deacetylation, thus play significant roles in regulating immune cells. HDAC5 deficient mice displayed a reduced production of Treg cells as well as less Treg cells induced when lack of HDAC5 in naïve CD4+ T cell upon Treg polarizing conditions [59]. Aforementioned, TSDR region is also regulated by a group of permissive histone marks, such as histone $\mathrm{H} 3$ acetylation and H3K4me3 [40,60].

Th9 and Tfh cell. A recent study has deciphered that via inhibiting repressive histone methylation induce Th9-specific PU.1 expression, which conversely, preventing histone acetylation to diminish PU.1 expression after IL-9-inducing stimulation. This result suggests that epigenetic modifications of PU.1 are unique for regulating Th9 differentiation [61]. Smad2 and Smad4, two transcriptional factors initiated by TGF-beta signaling pathway, are required for Th9 differentiation in vitro. Impaired IL-9 expression can be induced by Smad2 or Smad4 deficiency in T cells, and this may be caused by the repressive chromatin modification histone H3K27 trimethylation and enhanced EZH2 binding to the IL9 locus 


\section{Cellular Physiology Cell Physiol Biochem 2017;41:645-660 \\ \begin{tabular}{ll|l} 
and Biochemistry & $\begin{array}{l}\text { DOI: 10.1159/000457944 } \\
\text { Publisned onlne: February 06, } 2017\end{array}$ & $\begin{array}{l}\text { O } 2017 \text { The Author(s). Published by S. Karger AG, Basel } \\
\text { www.karger.com/cpb }\end{array}$ \\
\cline { 2 - 3 }
\end{tabular} \\ Wang/Wang/Lu: Epigenetics in Immune System and Autoimmune Diseases}

[62]. A recent study identified a demand of ETS transcription factor ETS variant 5 (ETV5) to augment IL-9+ Th9 cells with an enrichment of histone acetyltransferases (HATs) within the IL-9 gene promoter. In vitro study showed that a reduction of p300 in the absence of ETV5, accompanied by low level of histone H3 acetylation and H4K16 acetylation enriched in the Il9 promoter [63].

In addition to Th9, epigenetics have also established roles in Tfh differentiation. A great mapping of epigenetic profiles addresses that Tbx21, Gata3, and Rorc loci present permissive translational activities in Tfh cells. Conversely, a finding of H3K4me3 accumulation within Bcl6 gene locus in most non-Tfh cell implies the function of $\mathrm{T}$ helper cell lineages to display characteristic factors of Tfh cells upon stimulation [62]. (Fig. 2)

MiRNAs

Th1 and Th2 cells. The studies of miRNAs in T helper cell were first identified in Dicerdeficient CD 4+ T cells the studies with that Th cell differentiation was regulated by miRNA. The secretion of Th1 cell specific cytokine IFN $\gamma$ and transcription factor T-bet in Dicer-deficient Th2 cells strongly suggest that miRNAs play negative roles during the differentiation stage, [64] since Dicer is a RNase III enzymes essential for obtaining mature miRNA [65]. Increased expression of miR-29 in naive T cells has substantially comprimised Th1 cell differentiation by targeting several important factors, such as Tet (Tbx21) and eomesodermin (Ecomes). In addition, reduced expression of miR-29a in transgenic mice is proved to elevate the serum IFN $\gamma$ levels, suggesting that miR-29a perform the function by regulating IFN $\gamma$ mRNA expression. Compared with Th1 cells, regulation of Th2 cell differentiation by miRNA still needs more investigation. The study has also confirmed the role of miR-21 in T cells to promote Th2 cell differentiation in vitro [66], whilst IL-4 and IL-5 secretion are reduced under the regulation of miR27 or miR128 [67].

Th17 cell. miRNA has an ancillary role in Th17 cell differentiation. It has been identified that several noncoding sequences in the IL-17/IL-17F locus were kept across species.[38] Studies have found that miR-155 play a active role in promoting Th1 cells and Th17 cells differentiation during the induction phase of experimental autoimmune encephalomyelitis (EAE), which is a disease model of the Multiple sclerosis. MiR-326 proves to suppress the expression of Ets-1- a negative regulator of Th17 differentiation, thus promoting differentiation [68]. These together imply that miRNAs are associated with the generation and growth of both Th1/17 cells and Tregs. The RORC gene, which is required for Th17 development, is associated with prominent H3K4me3 epigenetic marks in Th17 cells [36], and is proved to be marked at the Il17 and Il17f locus [38]. The methylation in the Il17a promoter represses its combination with the STAT3, thus inhibiting the transcription regulation during the Th17 cell differentiation [39].

Treg cell. Dicer deletion in CD4-cre model induces the decreasing numbers of Tregs [69], implying that microRNAs play central roles in Treg proliferation. MiRNA-155 defects in Treg cells of mice, indicating a reduction in numbers of Tregs due to the Foxp3 regulation of miR155 represses SOCS- 1 thus increasing sensitivity of Tregs. Otherwise, miR-21 acts as a positive regulator of Foxp3 expression, therefore, contributes a prominent role in Treg cells [70].

The differentiation of Tfh cells is differentially regulated by a list of microRNAs due to their variant functions in transcriptional factors or regulatory elements. The miRNA events contributes a significant part to determine Tfh cell differentiation with two enhancers as miR-17 92 [71, 72] and miR-155 [73] as well as an dampened character miR-146a [74], thus establishing a comprehensive adjusting system to induced Tfh cell. (Fig. 1, 2)

Autoimmune diseases and epigenetic modifications. The risk factors provide us a variety of landscapes in explaining the etiology of autoimmune diseases, however, discordance rates between monozygotic twins remind us that many epigenetic mechanisms are still undetermined and are waiting us to explore in autoimmune diseases. (Fig. 3). 
Fig. 3. Epigenetic mechanism of $\mathrm{T}$ Cells in the Pathogenesis of Autoimmune Diseases. These mechanisms include DNA methylation, histone post-translational modifications, and small interfering RNAs, which can alter genome and produce a different gene expression profile. This figure deciphers a schematic representation of some aberrant epigenetic patterns involved in autoimmune diseases.

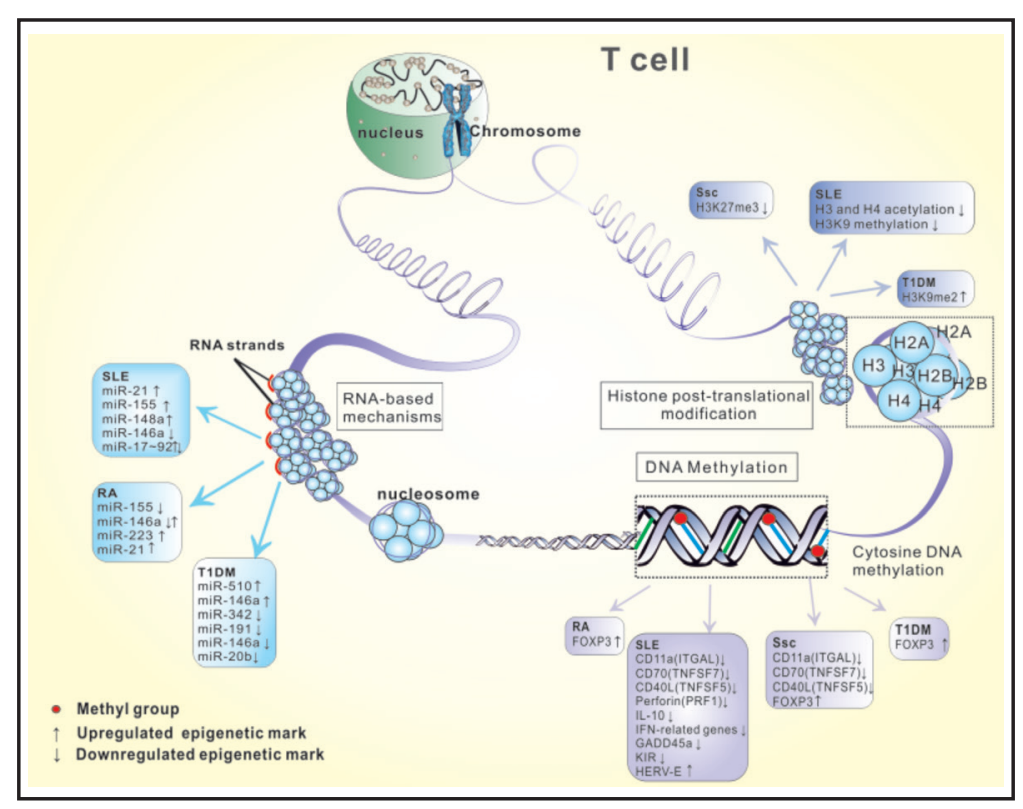

Systemic lupus erythematosus (SLE)

SLE is a common autoimmune disease especially occurred in women and caused by multifactorial elements that produce autoantibodies and inflammatory responses in organs and tissues. Desregulated T lymphocytes in SLE generate a series of aberrant immune dysfunctions that make the disease complicated and hard to handle. Although gene susceptibility have revealed an part of the profound mechanisms of SLE, the concordance rates in monozygotic twins of lower than 50\% [75] strongly suggests that epigenetics and environmental problems are involved in the onset and progression of the disease [76].

Epigenome study uncover the epigenetic spectrum in SLE T cells

Epigenetic studies of SLE started from the discovery of globally reduced DNA methylation in lupus T cells. $[77,78]$ The association between wide-ranged DNA hypomethylation in lupus and disease activity is on the basis of the study that applying DNA methylation inhibitors in CD4+ T cells would lead to a lupus-like syndrome. Recent studies applying sequence analysis technology have gained meaningful results that provide us with more information about lupus heritability [79], ethnicity variance [80] and renal involvement with DNA methylome analysis in CD4+ T cells [81]. Coit et al. confirmed a group of interferon-related genes that are aberrantly hypomethylated, including IFN-induced protein 44-like (IFI44L), IFN-induced protein with tetratricopeptide (IFIT1), IFIT3, MX dynamin-like GTPase 1 (MX1), signal transducer and activator of transcription 1 (STAT-1), bone marrow stromal cell antigen 2 (BST2) and tripartite motif containing 22 (TRIM22), in lupus CD4+ T cells [82]. Furthermore, a newly identified IFN-related gene IFI44L has been deciphered in SLE, and the study also emphasized its potential role as a diagnostic biomarker [83]. Furthermore, the globally reduced histone acetylation in lupus CD4+ T cells has been confirmed, implicating a number of aberrantly regulated genes [84-86]. In addition, a global histone H3K9 hypomethylation has also been found in CD4+ T cells. However, there is no evidence to connect the histone modifications with disease activity [84].

Methylation-sensitive genes in lupus CD4+T cells

In SLE, a wide range of hypomethylated genes in $\mathrm{T}$ lymphocytes have been reported, the methylation sensitive genes such as CD11a (ITGAL), perforin (PRF1), CD70 (TNFSF7), and CD40LG (TNFSF5) are significantly increased [87]. The promoter regions of CD11a and CD70 are recruited with decreased DNA methylation and increased histone acetylation which contributes to gene overexpression. The function of the two regulatory genes is noted 


\section{Cellular Physiology Cell Physiol Biochem 2017;41:645-660

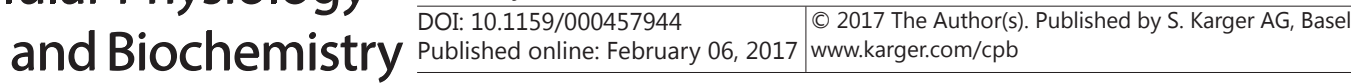 \\ Wang/Wang/Lu: Epigenetics in Immune System and Autoimmune Diseases}

with their autoimmune responses in CD4+ T cells of patients with SLE [88]. Relevant study has shown that perforin overexpression in CD4+ T cells from patients with active lupus were also caused by DNA demethylation [89]. Although the reason why systemic lupus erythematosus primarily affects women still remains undetermined, demethylation of CD40LG may contribute to the female susceptibility of this disease [90]. Reducing Regulatory factor X1 (RFX1) and the Nuclear factor interleukin-3-regulated protein (NFIL3, also known as E4BP4) were also differentially methylated as in our previous study in CD4+ T cells. Reduced Regulatory factor X1 (RFX1) levels lead to CD4+ T cell autoreactivity by promoting CD11a and CD70 overexpression with less DNMTs as well as more histone methyltransferase SUV39H1 recruitment in CD4+ T cells [91, 92]. Overexpression of the transcription regulator E4BP4 (NFIL3) generates a protective mechanisms in CD4(+)T cells through inhibiting CD40L expression, therefore downregulating the autoimmune responses in SLE patients [93]. Enhanced expression of IL-10 in T cells from SLE is regulated by aberrant activation of Stat3 with histone acetyltransferase p300. Therefore, overexpression of IL10 contributes to autoantibody production and tissue damage [94]. Similarly, in SLE T-cells, Sunahori et al. demonstrated that inhibiting catalytic subunit of protein phosphatase 2A (PP2Ac) resulted in increased MEK/ERK phosphorylation, elevated DNA methylation enriched with DNMTs, as well as decreased expression of CD70 gene. Disturbance of the methylation-sensitive genes are tightly associated with SLE pathogenesis [95]. Likewise, expression level of the growth arrest and DNA damage-induced 45a (GADD45a) is increased. Our previous work showed a negative correlation between the GADD45a and DNA methylation in human lupus CD4+ T cells [96]. Killer-cell immunoglobulin-like receptor (KIR) genes are specifically expressed on NK cells. KIR promoter region is enriched with methylation regulated loci and studies have found that KIR gene is overexpressed in lupus CD4+ T cells with DNA demethylation regulation, thus promoting the generation of inflammatory cells and cytokines $[97,98]$. The human endogenous retrovirus type E (HERV-E) promoter recruits repressive modifications as DNA methylation thus suppressing its expression in lupus CD4+ T cells, which are implied to be linked with lupus progression [99].

\section{Environment exposure driven epigenetics in lupus T cell}

Environmental factors such as UV exposure, smoking, vitamin D and infections are long been discussed in SLE [100]. Here, we put more emphasize on some newly identified elements that contribute to lupus.

Even if UV exposure is not a novel factor in SLE, the mechanisms altered dynamic in different studies. UV exposure produces an increased expression of gadd45A and CD11a/ CD70, which suggested that ultraviolet, may create epigenetic changes since gadd45A is demethylated after UV-B irradiation [101]. High salt is a diver in many autoimmune diseases. Recently a study confirmed its role in SLE. High salty may be involved in SLE pathogenesis by promoting Tfh cell differentiation and commitment, which are significant players in lupus [102]. Exposed to oxidative stress may generated a lupus-like syndromes with increased serum anti-dsDNA antibody and glomerulonephritis in mice, due to the reason that oxidant is an associated with DNA demthylation [103]. Icaritin (ICT) is an extract from a Chinese medicine that is efficient in immune responses due to its role to maintain the balance of Th17 and Treg cells. Studies further identified that ICT may be used as a drug in lupus for stabilizing Treg cell protective role in autoimmune reactions [104].

Distinct microRNAs independently or combined with DNA methylation to affect lupus pathogenesis

Several studies have begun to unravel the contributions of noncoding RNAs to lupus pathogenesis [105]. Indeed, seemingly dysfunctions are observed in aberrant immune responses in SLE. miR-21 and miR-148a, miR-126 are three methylation regulated microRNAs that are combined with a decreased expression of DNMTs in CD4+ T cells of SLE. More specifically, depletion of miR-21 in chronic graft-versus-host disease (cGVHD) model of SLE alleviates a series of autoimmune symptoms in lupus. In this model, miR-21 also affects 


\section{Cellular Physiology Cell Physiol Biochem 2017;41:645-660 \begin{tabular}{ll|l} 
DOI: 10.1159/000457944 2017 The Author(s). Published by S. Karger AG, Basel \\
and Biochemistry
\end{tabular} \\ Wang/Wang/Lu: Epigenetics in Immune System and Autoimmune Diseases}

T cell proportions with a reduced Th17 cell but an enhanced Treg cell [106, 107]. Previous study confirmed the mir-155 overexpression in Treg cells of MRL/lpr mice [108]. Further, mir-155 has been reported to have a regulation of T cell distribution as mir-155 deficiency mice displayed a reduced serum IL4 and IL17A which are two specific cytokines secreted by Th2 and Th17 cell separately. Similar to mir-21, lupus relevant clinical manifestations in the absence of mir-155 are milder than their controls [109]. miR-17 92 exhibits a controversial role in regulation Tfh cell differentiation. Previous study believed mir-17 92 limits Tfh cell differentiation since Bcl-6 could reverse the suppression role of mir-17 92 that inhibits CXCR5 expression in Tfh cells [110]. However, recent study doubted the thesis while lack of mir-17 92 promotes Tfh cell accumulation by targeting phosphatase PHLPP2 which is significant for T cell migration [72]. Accordingly, depletion or overexpression of mir-17 92 would lead a correspondence Tfh cell quantity as accompanied by subsequent autoimmune responses. mir-146a is a negative regulator in Tfh cell production, thus mir-146a deficiency mice may be resistant to lupus like symptoms [74].

\section{Rheumatoid arthritis (RA)}

RA is a chronic inflammatory diseases that specifically damage joints. Genome-wide study of DNA methylation in RA CD4+ T cells displayed a widely methylation variance in several regulatory genes or CpG sites. The specific mechanism of methotrexate (MTX) in RA has been revealed as MTX accumulates protective Treg cells by promoting the FOXP3 expression through promoter demethylation. Further to Treg cell, recent study identified that MTX treatment also reverse the hypomethylated status in PBMC cells of RA patients $[111,112]$. Similarly, all-trans retinoic acid performs its function as to stabilize FOXP3+ Treg cell efficacy under DNA methylation controlling [113].

Studies attempting to explore the functions of microRNAs on RA pathogenesis are gaining momentum [114]. Li et al. developed a microRNA expression profile analysis indicating the expression variance of microRNAs in CD4+ T cells of RA patients. The upregulation of miR$146 \mathrm{a}$ as well as downregulation of miR-363 and miR-498 has been recorded [115]. Further study confirmed the increased expression of miR-146a in CD4+ T cell of RA patients [115]. However, there are different opinions when a study drew an opposite conclusion that miR-146a and miR-155 are decreased in Treg cells in response to T cell stimulation of RA patients [116].Also, mir-126a expression is elevated in RA patients, which in turn increased expression of CD11a and CD70 by inducing DNA hypomethylation in their promoter region [117]. Reduced expression of miR-21 has been found in RA patients and study perceives that the decreased mir-21 would contribute Th17/Treg cell imbalance [118]. Further, increased expression of miR-21 has been found and it was believed to increase the accumulation of Treg cells in RA patients synovial fibroblasts [119].

\section{Systemic sclerosis (SSc)}

SSc is an autoimmune connective tissue disease with a high mortality. Early studies had shown whole genome wide DNA methylation signature of a list of target genes in CD4+ T cells. The decreased methylation level is induced by the downregulation of functional enzymes such as DNMT1, MBD3, and MBD4 [120]. Many methylation sensitive genes are involved in SSc pathogenesis and induced by DNA hypomethylation in their promoter sites. Overexpression of CD40L, CD11a and CD70 has been demonstrated as a predominant feature of SSc due to global reduced DNA methylation [121-123]. Despite the wide-ranged hypomethylation, Foxp3 promoter region gains hypermethylation mark that limits proliferation and functional activity of Treg cells [124]. Posttranslational modifications of CD4+ T cells in SSc exhibit globally reduced H3K27me3 thus resulting in accumulation of JMJD3 in SSc CD4+ T cells [125].

Type 1 diabetes mellitus (T1DM)

T1D is a chronic autoimmune disorder leading to the destruction of the beta cells with a strong inflammatory response through a mechanism mediated with $\mathrm{T}$ cells. It has 


\section{Cellular Physiology Cell Physiol Biochem 2017;41:645-660 \begin{tabular}{ll|l} 
and Biochemistry & $\begin{array}{l}\text { DOI: 10.1159/000457944 } \\
\text { Publisned onlne: February 06, } 2017\end{array}$ & $\begin{array}{l}\text { 2017 The Author(s). Published by S. Karger AG, Basel } \\
\text { ww.com/cpb }\end{array}$ \\
\cline { 2 - 3 }
\end{tabular}

been reported that regulatory regions of FOXP3 in CD4+T cells was hypermethylated in T1D, resulting in reduced FOXP3 expression and fail to generate regulatory T cells [126]. In addition, Wang et al. claims that FOXP3 hypermethylation was induced by Toll like receptor 9 (TLR9), in conjugation with a decreasing binding activity of Interferon regulator factor 7 (IRF-7) [127]. Emerging evidence has indicated that the aberrant histone modifications were also involved in T1D. CLTA4 is a T1DM susceptibility gene. The enrichment of histone H3 lysine 9 dimethylation (H3K9me2) in the promoter of CLTA4 was tightly correlated with $\mathrm{T}$ cells activation [128]. It has been suggested that Trichostatin A (TSA), an HDAC inhibitor, promotes IFN $-\gamma$ secretion and enhances the transcription activity of Tbx21 in T lymphocytes, therefore relieving the inflammatory cell infiltration of islets [129]. Moreover, T1DM exhibits a wide range of miRNA expression profiles. Studies have found an upregulation of miRNA-510 as well as a downregulation of miRNA-342 and miRNA-191. In addition, when comparing Tregs and other types of effector T cells, the results revealed a differential expression of miR146a and decreased expression of eight targeting miRNAs (20b, 31, 99a, 100, 125b, 151, 335, and 365) which support the involvement of microRNAs in T1D patients' Treg cells [130].

\section{Conclusion}

Inspired by overwhelming achievements in autoimmune diseases, a great deal of interest in immune cell and autoimmune reactions has focused on epigenetic determinants that are linked to three crucial areas of progress. Recent epigenetic therapies, such as DNA methyltransferase inhibitors, Histone deacetylase inhibitors, or BET bromodomain inhibitors [131] based on epigenetic mechanisms suggest the great potential for disease control and clinical relieve. HDAC inhibitors (HDACi) modulate immune and inflammatory processes, with a special emphasis on T-cell biology, consist of activating and differentiating naive $\mathrm{T}$ cells and developing featured T-cell subsets, particularly, Foxp3(+) Treg cells [132]. However, even though the translation of epigenetic mechanisms into clinical drug has been applied in cancer or other diseases, autoimmune diseases still lack the successful attempts. Whatever, the ability of epigenetic modification specifically regulates target regulatory region of a certain gene as well as monitor immune responses is promising for this technique in the treatment of autoimmune diseases.

\section{Acknowledgements}

This work was supported by the National Natural Science Foundation of China (no. 81270024, no. 81220108017 and no. 81430074), the Hunan Provincial Natural Science Foundation of China (14JJ1009), and the Fundamental Research Funds for the Central Universities of Central South University (2015zzts309).

\section{Disclosure Statement}

No potential conflicts of interest were disclosed.

\section{References}

1 Bird A: Perceptions of epigenetics. Nature 2007;447:396-398.

2 Moosavi A, Motevalizadeh Ardekani A: Role of Epigenetics in Biology and Human Diseases. Iran Biomed J 2016;20:246-258.

3 Bjornsson HT, Fallin MD, Feinberg AP: An integrated epigenetic and genetic approach to common human disease. Trends Genet 2004;20:350-358.

4 Vaissiere T, Sawan C, Herceg Z: Epigenetic interplay between histone modifications and DNA methylation in gene silencing. Mutat Res 2008;659:40-48.

5 Brenet F, Moh M, Funk P, Feierstein E, Viale AJ, Socci ND, Scandura JM: DNA methylation of the first exon is tightly linked to transcriptional silencing. PLoS One 2011;6:e14524. 


\section{Cellular Physiology Cell Physiol Biochem 2017;41:645-660

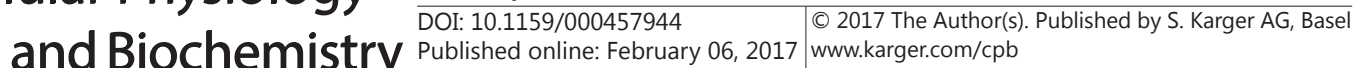 \\ Wang/Wang/Lu: Epigenetics in Immune System and Autoimmune Diseases}

6 Otagaki S, Kawai M, Masuta C, Kanazawa A: Size and positional effects of promoter RNA segments on virusinduced RNA-directed DNA methylation and transcriptional gene silencing. Epigenetics 2011;6:681-691.

7 Smith ZD, Meissner A: DNA methylation: roles in mammalian development. Nat Rev Genet 2013;14:204220.

8 Jeffries MA, Sawalha AH: Epigenetics in systemic lupus erythematosus: leading the way for specific therapeutic agents. Int J Clin Rheumtol 2011;6:423-439.

-9 Renaudineau Y, Youinou P: Epigenetics and autoimmunity, with special emphasis on methylation. Keio J Med 2011;60:10-16.

10 Hedrich CM, Tsokos GC: Epigenetic mechanisms in systemic lupus erythematosus and other autoimmune diseases. Trends Mol Med 2011;17:714-724.

11 Bannister AJ, Kouzarides T: Regulation of chromatin by histone modifications. Cell Res 2011;21:381-395.

12 Dieker J, Muller S: Epigenetic histone code and autoimmunity. Clin Rev Allergy Immunol 2010;39:78-84.

13 Cheung P, Lau P: Epigenetic regulation by histone methylation and histone variants. Mol Endocrinol 2005;19:563-573.

14 Zhu J, Yamane H, Paul WE: Differentiation of effector CD4 T cell populations ${ }^{*}$ ). Annu Rev Immunol 2010;28:445-489.

-15 Turner ML, Schnorfeil FM, Brocker T: MicroRNAs regulate dendritic cell differentiation and function. J Immunol 2011;187:3911-3917.

16 Bartel DP: MicroRNAs: genomics, biogenesis, mechanism, and function. Cell 2004;116:281-297.

17 Wang Z, Yin H, Lau CS, Lu Q: Histone Posttranslational Modifications of CD4(+) T Cell in Autoimmune Diseases. Int J Mol Sci 2016;17.

18 Zhao M, Wang Z, Yung S, Lu Q: Epigenetic dynamics in immunity and autoimmunity. Int J Biochem Cell Biol 2015;67:65-74.

19 Chen L, Ge B, Casale FP, Vasquez L, Kwan T, Garrido-Martin D, Watt S, Yan Y, Kundu K, Ecker S, Datta A, Richardson D, Burden F, Mead D, Mann AL, Fernandez JM, Rowlston S, Wilder SP, Farrow S, Shao X, Lambourne JJ, Redensek A, Albers CA, Amstislavskiy V, Ashford S, Berentsen K, Bomba L, Bourque G, Bujold D, Busche S, Caron M, Chen SH, Cheung W, Delaneau O, Dermitzakis ET, Elding H, Colgiu I, Bagger FO, Flicek P, Habibi E, Iotchkova V, Janssen-Megens E, Kim B, Lehrach H, Lowy E, Mandoli A, Matarese F, Maurano MT, Morris JA, Pancaldi V, Pourfarzad F, Rehnstrom K, Rendon A, Risch T, Sharifi N, Simon MM, Sultan M, Valencia A, Walter K, Wang SY, Frontini M, Antonarakis SE, Clarke L, Yaspo ML, Beck S, Guigo R, Rico D, Martens JH, Ouwehand WH, Kuijpers TW, Paul DS, Stunnenberg HG, Stegle O, Downes K, Pastinen T, Soranzo N: Genetic Drivers of Epigenetic and Transcriptional Variation in Human Immune Cells. Cell 2016;167:1398-1414 e1324.

20 Cua DJ, Sherlock J, Chen Y, Murphy CA, Joyce B, Seymour B, Lucian L, To W, Kwan S, Churakova T, Zurawski S, Wiekowski M, Lira SA, Gorman D, Kastelein RA, Sedgwick JD: Interleukin-23 rather than interleukin-12 is the critical cytokine for autoimmune inflammation of the brain. Nature 2003;421:744-748.

-21 Harrington LE, Hatton RD, Mangan PR, Turner H, Murphy TL, Murphy KM, Weaver CT: Interleukin 17-producing CD4+ effector T cells develop via a lineage distinct from the Thelper type 1 and 2 lineages. Nat Immunol 2005;6:1123-1132.

22 Park H, Li Z, Yang XO, Chang SH, Nurieva R, Wang YH, Wang Y, Hood L, Zhu Z, Tian Q Dong C: A distinct lineage of CD4 $\mathrm{T}$ cells regulates tissue inflammation by producing interleukin 17. Nat Immunol 2005;6:1133-1141.

23 Sakaguchi S, Sakaguchi N, Asano M, Itoh M, Toda M: Immunologic self-tolerance maintained by activated T cells expressing IL-2 receptor alpha-chains (CD25). Breakdown of a single mechanism of self-tolerance causes various autoimmune diseases. J Immunol 1995;155:1151-1164.

24 Vent-Schmidt J, Han JM, MacDonald KG, Levings MK: The role of FOXP3 in regulating immune responses. Int Rev Immunol 2014;33:110-128.

25 Goswami R, Kaplan MH: Gcn5 is required for PU.1-dependent IL-9 induction in Th9 cells. J Immunol 2012;189:3026-3033.

26 Kaplan MH: Th9 cells: differentiation and disease. Immunol Rev 2013;252:104-115.

27 Tan C, Gery I: The unique features of Th9 cells and their products. Crit Rev Immunol 2012;32:1-10.

28 Schmitt E, Bopp T: Amazing IL-9: revealing a new function for an "old" cytokine. J Clin Invest 2012;122:3857-3859.

29 Crotty S: Follicular helper CD4 T cells (TFH). Annu Rev Immunol 2011;29:621-663. 


\section{Cellular Physiology Cell Physiol Biochem 2017;41:645-660

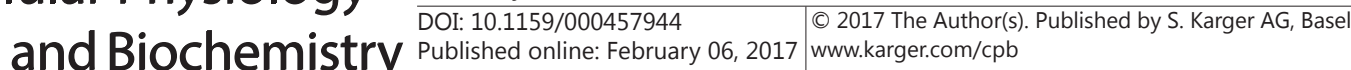 \\ Wang/Wang/Lu: Epigenetics in Immune System and Autoimmune Diseases}

30 Choi YS, Yang JA, Crotty S: Dynamic regulation of Bcl6 in follicular helper CD4 T (Tfh) cells. Curr Opin Immunol 2013;25:366-372.

- 31 Johnston RJ, Poholek AC, DiToro D, Yusuf I, Eto D, Barnett B, Dent AL, Craft J, Crotty S: Bcl6 and Blimp-1 are reciprocal and antagonistic regulators of T follicular helper cell differentiation. Science 2009;325:10061010.

-32 Lee GR, Kim ST, Spilianakis CG, Fields PE, Flavell RA: T helper cell differentiation: regulation by cis elements and epigenetics. Immunity 2006;24:369-379.

-33 Kondilis-Mangum HD, Wade PA: Epigenetics and the adaptive immune response. Mol Aspects Med 2013;34:813-825.

34 Roh TY, Cuddapah S, Zhao K: Active chromatin domains are defined by acetylation islands revealed by genome-wide mapping. Genes Dev 2005;19:542-552.

-35 Chou FC, Kuo CC, Chen HY, Chen HH, Sytwu HK: DNA demethylation of the TIM-3 promoter is critical for its stable expression on T cells. Genes Immun 2016;17:179-186.

-36 Wei G, Wei L, Zhu J, Zang C, Hu-Li J, Yao Z, Cui K, Kanno Y, Roh TY, Watford WT, Schones DE, Peng W, Sun HW, Paul WE, O'Shea JJ, Zhao K: Global mapping of H3K4me3 and H3K27me3 reveals specificity and plasticity in lineage fate determination of differentiating CD4+ T cells. Immunity 2009;30:155-167.

-37 Janson PC, Linton LB, Bergman EA, Marits P, Eberhardson M, Piehl F, Malmstrom V, Winqvist O: Profiling of CD4+ T cells with epigenetic immune lineage analysis. J Immunol 2011;186:92-102.

- 38 Akimzhanov AM, Yang XO, Dong C: Chromatin remodeling of interleukin-17 (IL-17)-IL-17F cytokine gene locus during inflammatory helper T cell differentiation. J Biol Chem 2007;282:5969-5972.

-39 Thomas RM, Sai H, Wells AD: Conserved intergenic elements and DNA methylation cooperate to regulate transcription at the il17 locus. J Biol Chem 2012;287:25049-25059.

- 40 Floess S, Freyer J, Siewert C, Baron U, Olek S, Polansky J, Schlawe K, Chang HD, Bopp T, Schmitt E, KleinHessling S, Serfling E, Hamann A, Huehn J: Epigenetic control of the foxp3 locus in regulatory T cells. PLoS Biol 2007;5:e38.

-41 Yue X, Trifari S, Aijo T, Tsagaratou A, Pastor WA, Zepeda-Martinez JA, Lio CW, Li X, Huang Y, Vijayanand P, Lahdesmaki H, Rao A: Control of Foxp3 stability through modulation of TET activity. J Exp Med 2016;213:377-397.

42 Ngalamika O, Liang G, Zhao M, Yu X, Yang Y, Yin H, Liu Y, Yung S, Chan TM, Lu Q: Peripheral whole blood FOXP3 TSDR methylation: a potential marker in severity assessment of autoimmune diseases and chronic infections. Immunol Invest 2015;44:126-136.

43 Barzaghi F, Passerini L, Gambineri E, Ciullini Mannurita S, Cornu T, Kang ES, Choe YH, Cancrini C, Corrente S, Ciccocioppo R, Cecconi M, Zuin G, Discepolo V, Sartirana C, Schmidtko J, Ikinciogullari A, Ambrosi A, Roncarolo MG, Olek S, Bacchetta R: Demethylation analysis of the FOXP3 locus shows quantitative defects of regulatory T cells in IPEX-like syndrome. J Autoimmun 2012;38:49-58.

44 Kitagawa Y, Ohkura N, Sakaguchi S: Epigenetic control of thymic Treg-cell development. Eur J Immunol 2015;45:11-16.

-45 Morikawa H, Ohkura N, Vandenbon A, Itoh M, Nagao-Sato S, Kawaji H, Lassmann T, Carninci P, Hayashizaki Y, Forrest AR, Standley DM, Date H, Sakaguchi S, Consortium F: Differential roles of epigenetic changes and Foxp3 expression in regulatory T cell-specific transcriptional regulation. Proc Natl Acad Sci U S A 2014;111:5289-5294.

46 Schreiber L, Pietzsch B, Floess S, Farah C, Jansch L, Schmitz I, Huehn J: The Treg-specific demethylated region stabilizes Foxp3 expression independently of NF-kappaB signaling. PLoS One 2014;9:e88318.

47 Waight JD, Takai S, Marelli B, Qin G, Hance KW, Zhang D, Tighe R, Lan Y, Lo KM, Sabzevari H, Hofmeister R, Wilson NS: Cutting Edge: Epigenetic Regulation of Foxp3 Defines a Stable Population of CD4+ Regulatory T Cells in Tumors from Mice and Humans. J Immunol 2015;194:878-882.

-48 Lu CH, Wu CJ, Chan CC, Nguyen DT, Lin KR, Lin SJ, Chen LC, Yen JJ, Kuo ML: DNA Methyltransferase Inhibitor Promotes Human CD4+CD25hFOXP3+ Regulatory T Lymphocyte Induction under Suboptimal TCR Stimulation. Front Immunol 2016;7:488.

49 Ansel KM, Djuretic I, Tanasa B, Rao A: Regulation of Th2 differentiation and Il4 locus accessibility. Annu Rev Immunol 2006;24:607-656.

-50 Ansel KM, Greenwald RJ, Agarwal S, Bassing CH, Monticelli S, Interlandi J, Djuretic IM, Lee DU, Sharpe AH, Alt FW, Rao A: Deletion of a conserved Il4 silencer impairs T helper type 1-mediated immunity. Nat Immunol 2004;5:1251-1259. 


\section{Cellular Physiology Cell Physiol Biochem 2017;41:645-660

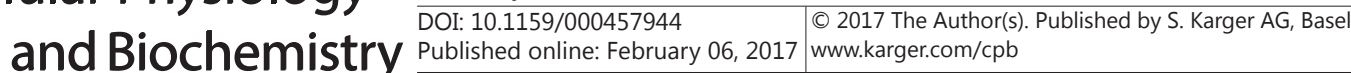 \\ Wang/Wang/Lu: Epigenetics in Immune System and Autoimmune Diseases}

51 Messi M, Giacchetto I, Nagata K, Lanzavecchia A, Natoli G, Sallusto F: Memory and flexibility of cytokine gene expression as separable properties of human $\mathrm{T}(\mathrm{H}) 1$ and $\mathrm{T}(\mathrm{H}) 2$ lymphocytes. Nat Immunol 2003;4:7886.

-52 Yamashita M, Shinnakasu R, Nigo Y, Kimura M, Hasegawa A, Taniguchi M, Nakayama T: Interleukin (IL)-4independent maintenance of histone modification of the IL-4 gene loci in memory Th2 cells. J Biol Chem 2004;279:39454-39464.

53 Onodera A, Yamashita M, Endo Y, Kuwahara M, Tofukuji S, Hosokawa H, Kanai A, Suzuki Y, Nakayama T: STAT6-mediated displacement of polycomb by trithorax complex establishes long-term maintenance of GATA3 expression in T helper type 2 cells. J Exp Med 2010;207:2493-2506.

54 Yamashita M, Hirahara K, Shinnakasu R, Hosokawa H, Norikane S, Kimura MY, Hasegawa A, Nakayama T: Crucial role of MLL for the maintenance of memory T helper type 2 cell responses. Immunity 2006;24:611622.

-55 Suzuki J, Maruyama S, Tamauchi H, Kuwahara M, Horiuchi M, Mizuki M, Ochi M, Sawasaki T, Zhu J, Yasukawa M, Yamashita M: Gfi1, a transcriptional repressor, inhibits the induction of the Thelper type 1 programme in activated CD4 T cells. Immunology 2016;147:476-487.

>56 Liu Z, Cao W, Xu L, Chen X, Zhan Y, Yang Q, Liu S, Chen P, Jiang Y, Sun X, Tao Y, Hu Y, Li C, Wang Q, Wang Y, Chen CD, Shi Y, Zhang X: The histone H3 lysine-27 demethylase Jmjd3 plays a critical role in specific regulation of Th17 cell differentiation. J Mol Cell Biol 2015;7:505-516.

-57 Liu Y, Wang L, Han R, Beier UH, Akimova T, Bhatti T, Xiao H, Cole PA, Brindle PK, Hancock WW: Two histone/protein acetyltransferases, $\mathrm{CBP}$ and p300, are indispensable for Foxp3+ T-regulatory cell development and function. Mol Cell Biol 2014;34:3993-4007.

-58 Miyara M, Chader D, Burlion A, Goldstein J, Sterlin D, Norol F, Trebeden-Negre H, Claer L, Sakaguchi S, Marodon G, Amoura Z, Gorochov G: Combination of IL-2, rapamycin, DNA methyltransferase and histone deacetylase inhibitors for the expansion of human regulatory T cells. Oncotarget DOI:10.18632/ oncotarget.10914.

-59 Xiao H, Jiao J, Wang L, O'Brien S, Newick K, Wang LC, Falkensammer E, Liu Y, Han R, Kapoor V, Hansen FK, Kurz T, Hancock WW, Beier UH: HDAC5 controls the functions of Foxp3(+) T-regulatory and CD8(+) T cells. Int J Cancer 2016;138:2477-2486.

60 Sekiya T, Kashiwagi I, Inoue N, Morita R, Hori S, Waldmann H, Rudensky AY, Ichinose H, Metzger D, Chambon P, Yoshimura A: The nuclear orphan receptor Nr4a2 induces Foxp3 and regulates differentiation of CD4+ T cells. Nat Commun 2011;2:269.

61 Ramming A, Druzd D, Leipe J, Schulze-Koops H, Skapenko A: Maturation-related histone modifications in the PU.1 promoter regulate Th9-cell development. Blood 2012;119:4665-4674.

62 Wang A, Pan D, Lee YH, Martinez GJ, Feng XH, Dong C: Cutting edge: Smad2 and Smad4 regulate TGF-betamediated Il9 gene expression via EZH2 displacement. J Immunol 2013;191:4908-4912.

63 Koh B, Hufford MM, Pham D, Olson MR, Wu T, Jabeen R, Sun X, Kaplan MH: The ETS Family Transcription Factors Etv5 and PU.1 Function in Parallel To Promote Th9 Cell Development. J Immunol 2016;197:24652472.

64 Muljo SA, Ansel KM, Kanellopoulou C, Livingston DM, Rao A, Rajewsky K: Aberrant T cell differentiation in the absence of Dicer. J Exp Med 2005;202:261-269.

65 Carmell MA, Hannon GJ: RNase III enzymes and the initiation of gene silencing. Nat Struct Mol Biol 2004;11:214-218.

66 Sawant DV, Wu H, Kaplan MH, Dent AL: The Bcl6 target gene microRNA-21 promotes Th2 differentiation by a T cell intrinsic pathway. Mol Immunol 2013;54:435-442.

67 Guerau-de-Arellano M, Smith KM, Godlewski J, Liu Y, Winger R, Lawler SE, Whitacre CC, Racke MK, LovettRacke AE: Micro-RNA dysregulation in multiple sclerosis favours pro-inflammatory T-cell-mediated autoimmunity. Brain 2011;134:3578-3589.

-68 Du C, Liu C, Kang J, Zhao G, Ye Z, Huang S, Li Z, Wu Z, Pei G: MicroRNA miR-326 regulates TH-17 differentiation and is associated with the pathogenesis of multiple sclerosis. Nat Immunol 2009;10:12521259.

69 Cobb BS, Hertweck A, Smith J, O'Connor E, Graf D, Cook T, Smale ST, Sakaguchi S, Livesey FJ, Fisher AG, Merkenschlager M: A role for Dicer in immune regulation. J Exp Med 2006;203:2519-2527.

70 Rouas R, Fayyad-Kazan H, El Zein N, Lewalle P, Rothe F, Simion A, Akl H, Mourtada M, El Rifai M, Burny A, Romero P, Martiat P, Badran B: Human natural Treg microRNA signature: role of microRNA-31 and microRNA-21 in FOXP3 expression. Eur J Immunol 2009;39:1608-1618. 


\section{Cellular Physiology Cell Physiol Biochem 2017;41:645-660

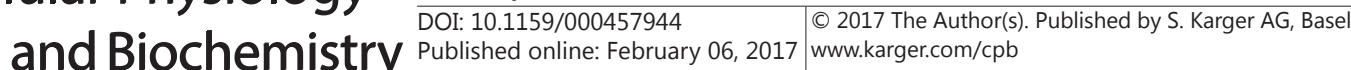 \\ Wang/Wang/Lu: Epigenetics in Immune System and Autoimmune Diseases}

71 Baumjohann D, Kageyama R, Clingan JM, Morar MM, Patel S, de Kouchkovsky D, Bannard O, Bluestone JA, Matloubian M, Ansel KM, Jeker LT: The microRNA cluster miR-17 approximately 92 promotes TFH cell differentiation and represses subset-inappropriate gene expression. Nat Immunol 2013;14:840-848.

72 Kang SG, Liu WH, Lu P, Jin HY, Lim HW, Shepherd J, Fremgen D, Verdin E, Oldstone MB, Qi H, Teijaro JR, Xiao C: MicroRNAs of the miR-17 approximately 92 family are critical regulators of T(FH) differentiation. Nat Immunol 2013;14:849-857.

73 Hu R, Kagele DA, Huffaker TB, Runtsch MC, Alexander M, Liu J, Bake E, Su W, Williams MA, Rao DS, Moller T, Garden GA, Round JL, O'Connell RM: miR-155 promotes T follicular helper cell accumulation during chronic, low-grade inflammation. Immunity 2014;41:605-619.

74 Pratama A, Srivastava M, Williams NJ, Papa I, Lee SK, Dinh XT, Hutloff A, Jordan MA, Zhao JL, Casellas R, Athanasopoulos V, Vinuesa CG: MicroRNA-146a regulates ICOS-ICOSL signalling to limit accumulation of T follicular helper cells and germinal centres. Nat Commun 2015;6:6436.

75 Deapen D, Escalante A, Weinrib L, Horwitz D, Bachman B, Roy-Burman P, Walker A, Mack TM: A revised estimate of twin concordance in systemic lupus erythematosus. Arthritis Rheum 1992;35:311-318.

76 Pan Y, Sawalha AH: Epigenetic regulation and the pathogenesis of systemic lupus erythematosus. Transl Res 2009;153:4-10.

77 Richardson B, Scheinbart L, Strahler J, Gross L, Hanash S, Johnson M: Evidence for impaired T cell DNA methylation in systemic lupus erythematosus and rheumatoid arthritis. Arthritis Rheum 1990;33:16651673.

78 Chen SH, Lv QL, Hu L, Peng MJ, Wang GH, Sun B: DNA methylation alterations in the pathogenesis of lupus. Clin Exp Immunol DOI:10.1111/cei.12877.

79 Sun C, Molineros JE, Looger LL, Zhou XJ, Kim K, Okada Y, Ma J, Qi YY, Kim-Howard X, Motghare P, Bhattarai K, Adler A, Bang SY, Lee HS, Kim TH, Kang YM, Suh CH, Chung WT, Park YB, Choe JY, Shim SC, Kochi Y, Suzuki A, Kubo M, Sumida T, Yamamoto K, Lee SS, Kim YJ, Han BG, Dozmorov M, Kaufman KM, Wren JD, Harley JB, Shen N, Chua KH, Zhang H, Bae SC, Nath SK: High-density genotyping of immune-related loci identifies new SLE risk variants in individuals with Asian ancestry. Nat Genet 2016;48:323-330.

-80 Coit P, Ognenovski M, Gensterblum E, Maksimowicz-McKinnon K, Wren JD, Sawalha AH: Ethnicity-specific epigenetic variation in naive CD4+ T cells and the susceptibility to autoimmunity. Epigenetics Chromatin 2015;8:49.

81 Coit P, Renauer P, Jeffries MA, Merrill JT, McCune WJ, Maksimowicz-McKinnon K, Sawalha AH: Renal involvement in lupus is characterized by unique DNA methylation changes in naive CD4+ T cells. J Autoimmun 2015;61:29-35.

82 Coit P, Jeffries M, Altorok N, Dozmorov MG, Koelsch KA, Wren JD, Merrill JT, McCune WJ, Sawalha AH: Genome-wide DNA methylation study suggests epigenetic accessibility and transcriptional poising of interferon-regulated genes in naive CD4+ T cells from lupus patients. J Autoimmun 2013;43:78-84.

83 Zhao M, Zhou Y, Zhu B, Wan M, Jiang T, Tan Q, Liu Y, Jiang J, Luo S, Tan Y, Wu H, Renauer P, Del Mar Ayala Gutierrez M, Castillo Palma MJ, Ortega Castro R, Fernandez-Roldan C, Raya E, Faria R, Carvalho C, AlarconRiquelme ME, Xiang Z, Chen J, Li F, Ling G, Zhao H, Liao X, Lin Y, Sawalha AH, Lu Q: IFI44L promoter methylation as a blood biomarker for systemic lupus erythematosus. Ann Rheum Dis 2016;75:1998-2006.

-84 Hu N, Qiu X, Luo Y, Yuan J, Li Y, Lei W, Zhang G, Zhou Y, Su Y, Lu Q: Abnormal histone modification patterns in lupus CD4+ T cells. J Rheumatol 2008;35:804-810.

85 Javierre BM, Richardson B: A new epigenetic challenge: systemic lupus erythematosus. Adv Exp Med Biol 2011;711:117-136.

-86 Zhang Z, Maurer K, Perin JC, Song L, Sullivan KE: Cytokine-induced monocyte characteristics in SLE. J Biomed Biotechnol 2010;2010:507475.

87 Richardson B: Primer: epigenetics of autoimmunity. Nat Clin Pract Rheumatol 2007;3:521-527.

-88 Lu Q, Kaplan M, Ray D, Ray D, Zacharek S, Gutsch D, Richardson B: Demethylation of ITGAL (CD11a) regulatory sequences in systemic lupus erythematosus. Arthritis Rheum 2002;46:1282-1291.

89 Kaplan MJ, Lu Q Wu A, Attwood J, Richardson B: Demethylation of promoter regulatory elements contributes to perforin overexpression in CD4+ lupus T cells. J Immunol 2004;172:3652-3661.

-90 Lu Q, Wu A, Tesmer L, Ray D, Yousif N, Richardson B: Demethylation of CD40LG on the inactive X in T cells from women with lupus. J Immunol 2007;179:6352-6358.

91 Zhao M, Sun Y, Gao F, Wu X, Tang J, Yin H, Luo Y, Richardson B, Lu Q: Epigenetics and SLE: RFX1 downregulation causes CD11a and CD70 overexpression by altering epigenetic modifications in lupus CD4+ T cells. J Autoimmun 2010;35:58-69. 


\section{Cellular Physiology Cell Physiol Biochem 2017;41:645-660

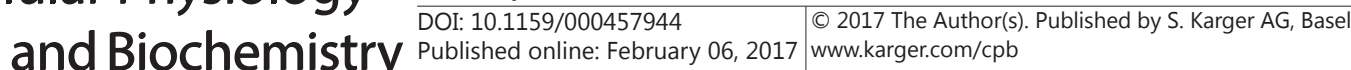 \\ Wang/Wang/Lu: Epigenetics in Immune System and Autoimmune Diseases}

-92 Zhao M, Wu X, Zhang Q, Luo S, Liang G, Su Y, Tan Y, Lu Q: RFX1 regulates CD70 and CD11a expression in lupus $\mathrm{T}$ cells by recruiting the histone methyltransferase SUV39H1. Arthritis Res Ther 2010;12:R227.

93 Zhao M, Liu Q, Liang G, Wang L, Luo S, Tang Q Zhao H, Su Y, Yung S, Chan TM, Lu Q: E4BP4 overexpression: a protective mechanism in CD4+ T cells from SLE patients. J Autoimmun 2013;41:152-160.

$\$ 94$ Hedrich CM, Rauen T, Apostolidis SA, Grammatikos AP, Rodriguez Rodriguez N, Ioannidis C, Kyttaris VC, Crispin JC, Tsokos GC: Stat3 promotes IL-10 expression in lupus T cells through trans-activation and chromatin remodeling. Proc Natl Acad Sci U S A 2014;111:13457-13462.

-95 Sunahori K, Nagpal K, Hedrich CM, Mizui M, Fitzgerald LM, Tsokos GC: The catalytic subunit of protein phosphatase 2A (PP2Ac) promotes DNA hypomethylation by suppressing the phosphorylated mitogenactivated protein kinase/extracellular signal-regulated kinase (ERK) kinase (MEK)/phosphorylated ERK/ DNMT1 protein pathway in T-cells from controls and systemic lupus erythematosus patients. J Biol Chem 2013;288:21936-21944.

96 Li Y, Huang C, Zhao M, Liang G, Xiao R, Yung S, Chan TM, Lu Q: A possible role of HMGB1 in DNA demethylation in CD4+ T cells from patients with systemic lupus erythematosus. Clin Dev Immunol 2013;2013:206298.

-97 Basu D, Liu Y, Wu A, Yarlagadda S, Gorelik GJ, Kaplan MJ, Hewagama A, Hinderer RC, Strickland FM, Richardson BC: Stimulatory and inhibitory killer Ig-like receptor molecules are expressed and functional on lupus T cells. J Immunol 2009;183:3481-3487.

-98 Liu Y, Kuick R, Hanash S, Richardson B: DNA methylation inhibition increases T cell KIR expression through effects on both promoter methylation and transcription factors. Clin Immunol 2009;130:213-224.

-99 Wu Z, Mei X, Zhao D, Sun Y, Song J, Pan W, Shi W: DNA methylation modulates HERV-E expression in CD4+ T cells from systemic lupus erythematosus patients. J Dermatol Sci 2015;77:110-116.

100 Long H, Yin H, Wang L, Gershwin ME, Lu Q: The critical role of epigenetics in systemic lupus erythematosus and autoimmunity. J Autoimmun 2016;74:118-138.

101 Li Y, Zhao M, Yin H, Gao F, Wu X, Luo Y, Zhao S, Zhang X, Su Y, Hu N, Long H, Richardson B, Lu Q: Overexpression of the growth arrest and DNA damage-induced 45alpha gene contributes to autoimmunity by promoting DNA demethylation in lupus T cells. Arthritis Rheum 2010;62:1438-1447.

102 Wu H, Huang X, Qiu H, Zhao M, Liao W, Yuan S, Xie Y, Dai Y, Chang C, Yoshimura A, Lu Q: High salt promotes autoimmunity by TET2-induced DNA demethylation and driving the differentiation of Tfh cells. Sci Rep 2016;6:28065.

103 Strickland FM, Li Y, Johnson K, Sun Z, Richardson BC: CD4(+) T cells epigenetically modified by oxidative stress cause lupus-like autoimmunity in mice. J Autoimmun 2015;62:75-80.

104 Liao J, Liu Y, Wu H, Zhao M, Tan Y, Li D, Long H, Dai Y, Yung S, Chan TM, Lu Q: The role of icaritin in regulating Foxp3/IL17a balance in systemic lupus erythematosus and its effects on the treatment of MRL/ lpr mice. Clin Immunol 2016;162:74-83.

105 Xiao C, Rajewsky K: MicroRNA control in the immune system: basic principles. Cell 2009;136:26-36.

106 Pan W, Zhu S, Yuan M, Cui H, Wang L, Luo X, Li J, Zhou H, Tang Y, Shen N: MicroRNA-21 and microRNA148a contribute to DNA hypomethylation in lupus CD4+ T cells by directly and indirectly targeting DNA methyltransferase 1. J Immunol 2010;184:6773-6781.

107 Garchow B, Kiriakidou M: MicroRNA-21 deficiency protects from lupus-like autoimmunity in the chronic graft-versus-host disease model of systemic lupus erythematosus. Clin Immunol 2016;162:100-106.

-108 Divekar AA, Dubey S, Gangalum PR, Singh RR: Dicer insufficiency and microRNA-155 overexpression in lupus regulatory T cells: an apparent paradox in the setting of an inflammatory milieu. J Immunol 2011;186:924-930.

109 Xin Q, Li J, Dang J, Bian X, Shan S, Yuan J, Qian Y, Liu Z, Liu G, Yuan Q, Liu N, Ma X, Gao F, Gong Y, Liu Q: miR155 Deficiency Ameliorates Autoimmune Inflammation of Systemic Lupus Erythematosus by Targeting S1pr1 in Faslpr/lpr Mice. J Immunol 2015;194:5437-5445.

110 Yu D, Rao S, Tsai LM, Lee SK, He Y, Sutcliffe EL, Srivastava M, Linterman M, Zheng L, Simpson N, Ellyard JI, Parish IA, Ma CS, Li QJ, Parish CR, Mackay CR, Vinuesa CG: The transcriptional repressor Bcl-6 directs T follicular helper cell lineage commitment. Immunity 2009;31:457-468.

111 Cribbs AP, Kennedy A, Penn H, Amjadi P, Green P, Read JE, Brennan F, Gregory B, Williams RO: Methotrexate Restores Regulatory T Cell Function Through Demethylation of the FoxP3 Upstream Enhancer in Patients With Rheumatoid Arthritis. Arthritis Rheumatol 2015;67:1182-1192.

112 de Andres MC, Perez-Pampin E, Calaza M, Santaclara FJ, Ortea I, Gomez-Reino JJ, Gonzalez A: Assessment of global DNA methylation in peripheral blood cell subpopulations of early rheumatoid arthritis before and 


\section{Cellular Physiology Cell Physiol Biochem 2017;41:645-660

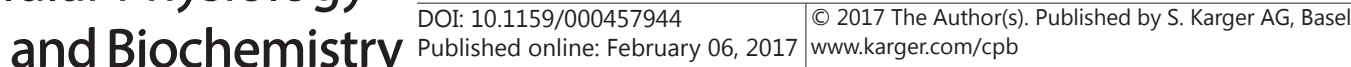

Wang/Wang/Lu: Epigenetics in Immune System and Autoimmune Diseases

after methotrexate. Arthritis Res Ther 2015;17:233.

113 Lu L, Lan Q, Li Z, Zhou X, Gu J, Li Q, Wang J, Chen M, Liu Y, Shen Y, Brand DD, Ryffel B, Horwitz DA, Quismorio FP, Liu Z, Li B, Olsen NJ, Zheng SG: Critical role of all-trans retinoic acid in stabilizing human natural regulatory T cells under inflammatory conditions. Proc Natl Acad Sci U S A 2014;111:E3432-3440.

-114 Churov AV, Oleinik EK, Knip M: MicroRNAs in rheumatoid arthritis: altered expression and diagnostic potential. Autoimmun Rev 2015;14:1029-1037.

115 Li J, Wan Y, Guo Q, Zou L, Zhang J, Fang Y, Zhang J, Zhang J, Fu X, Liu H, Lu L, Wu Y: Altered microRNA expression profile with miR-146a upregulation in CD4+ T cells from patients with rheumatoid arthritis. Arthritis Res Ther 2010;12:R81.

-116 Zhou Q, Haupt S, Kreuzer JT, Hammitzsch A, Proft F, Neumann C, Leipe J, Witt M, Schulze-Koops H, Skapenko A: Decreased expression of miR-146a and miR-155 contributes to an abnormal Treg phenotype in patients with rheumatoid arthritis. Ann Rheum Dis 2015;74:1265-1274.

117 Yang G, Wu D, Zeng G, Jiang O, Yuan P, Huang S, Zhu J, Tian J, Weng Y, Rao Z: Correlation between miR-126 expression and DNA hypomethylation of CD4+ T cells in rheumatoid arthritis patients. Int J Clin Exp Pathol 2015;8:8929-8936.

118 Dong L, Wang X, Tan J, Li H, Qian W, Chen J, Chen Q Wang J, Xu W, Tao C, Wang S: Decreased expression of microRNA-21 correlates with the imbalance of Th17 and Treg cells in patients with rheumatoid arthritis. J Cell Mol Med 2014;18:2213-2224.

-119 van der Geest KS, Smigielska-Czepiel K, Park JA, Abdulahad WH, Kim HW, Kroesen BJ, van den Berg A, Boots AM, Lee EB, Brouwer E: SF Treg cells transcribing high levels of Bcl-2 and microRNA-21 demonstrate limited apoptosis in RA. Rheumatology (Oxford) 2015;54:950-958.

120 Lei W, Luo Y, Lei W, Luo Y, Yan K, Zhao S, Li Y, Qiu X, Zhou Y, Long H, Zhao M, Liang Y, Su Y, Lu Q: Abnormal DNA methylation in CD4+ T cells from patients with systemic lupus erythematosus, systemic sclerosis, and dermatomyositis. Scand J Rheumatol 2009;38:369-374.

121 Lian X, Xiao R, Hu X, Kanekura T, Jiang H, Li Y, Wang Y, Yang Y, Zhao M, Lu Q: DNA demethylation of CD401 in CD4+ T cells from women with systemic sclerosis: a possible explanation for female susceptibility. Arthritis Rheum 2012;64:2338-2345.

122 Wang Y, Shu Y, Xiao Y, Wang Q, Kanekura T, Li Y, Wang J, Zhao M, Lu Q, Xiao R: Hypomethylation and overexpression of ITGAL (CD11a) in CD4(+) T cells in systemic sclerosis. Clin Epigenetics 2014;6:25.

123 Jiang H, Xiao R, Lian X, Kanekura T, Luo Y, Yin Y, Zhang G, Yang Y, Wang Y, Zhao M, Lu Q: Demethylation of TNFSF7 contributes to CD70 overexpression in CD4+ T cells from patients with systemic sclerosis. Clin Immunol 2012;143:39-44.

124 Wang YY, Wang Q, Sun XH, Liu RZ, Shu Y, Kanekura T, Huang JH, Li YP, Wang JC, Zhao M, Lu QJ, Xiao R: DNA hypermethylation of the forkhead box protein 3 (FOXP3) promoter in CD4+ T cells of patients with systemic sclerosis. Br J Dermatol 2014;171:39-47.

125 Wang Q, Xiao Y, Shi Y, Luo Y, Li Y, Zhao M, Lu Q Xiao R: Overexpression of JMJD3 may contribute to demethylation of H3K27me3 in CD4+ T cells from patients with systemic sclerosis. Clin Immunol 2015;161:396-399.

126 Li Y, Zhao M, Hou C, Liang G, Yang L, Tan Y, Wang Z, Yin H, Zhou Z, Lu Q: Abnormal DNA methylation in CD4+ T cells from people with latent autoimmune diabetes in adults. Diabetes Res Clin Pract 2011;94:242-248.

127 Wang Z, Zheng Y, Hou C, Yang L, Li X, Lin J, Huang G, Lu Q, Wang CY, Zhou Z: DNA methylation impairs TLR9 induced Foxp3 expression by attenuating IRF-7 binding activity in fulminant type 1 diabetes. J Autoimmun 2013;41:50-59.

128 Miao F, Smith DD, Zhang L, Min A, Feng W, Natarajan R: Lymphocytes from patients with type 1 diabetes display a distinct profile of chromatin histone H3 lysine 9 dimethylation: an epigenetic study in diabetes. Diabetes 2008;57:3189-3198.

129 Patel T, Patel V, Singh R, Jayaraman S: Chromatin remodeling resets the immune system to protect against autoimmune diabetes in mice. Immunol Cell Biol 2011;89:640-649.

130 Hezova R, Slaby O, Faltejskova P, Mikulkova Z, Buresova I, Raja KR, Hodek J, Ovesna J, Michalek J: microRNA-342, microRNA-191 and microRNA-510 are differentially expressed in T regulatory cells of type 1 diabetic patients. Cell Immunol 2010;260:70-74.

131 Tough DF, Tak PP, Tarakhovsky A, Prinjha RK: Epigenetic drug discovery: breaking through the immune barrier. Nat Rev Drug Discov DOI:10.1038/nrd.2016.185.

132 Akimova T, Beier UH, Liu Y, Wang L, Hancock WW: Histone/protein deacetylases and T-cell immune responses. Blood 2012;119:2443-2451. 